\title{
The Relationship Between Emotion Regulation and Resilience in Single Mothers Possessing Multiple Roles in Malang City
}

\section{Fyana Azara*, Aryudho Widyatno, Mohammad Bisrí, and Ayu Dyah Hapsari}

Psychology, State University of Malang, Malang

\section{ORCID}

Fyana Azara; https://orcid.org/0000-0003-3431-9434

\begin{abstract}
In reality, not all families consist of two parents; there are many single fathers and mothers. Single mothers have a responsibility in educating their children as well as being the backbone of the family - these two tasks are called dual roles. Multiple roles can cause conflict and negative emotions in single mothers. Therefore, it is important to be able to regulate emotions to run optimally, and it is important to have skills in resilience to rise from difficult experiences and be optimistic when facing problems. This study aimed to examine the relationship between emotion regulation and the resilience of single mothers who have multiple roles in Malang City. A quantitative research method was used and there were 80 participants who were all single mothers with multiple roles in Malang City. The measuring instruments used were the emotion regulation scale and the resilience scale. Based on the results, there was a significantly strong correlation between emotion regulation and resilience.
\end{abstract}

Corresponding Author: Fyana

Azara; email:

[10pt] Dates

Published 28 January 2022

Publishing services provided by Knowledge

(c) Fyana Azara et al. This article is distributed under the terms of the

Attribution License, which permits unrestricted use and redistribution provided that the original author and source are credited.

Selection and Peer-review under the responsibility of the ICoPsy Conference Committee.

\section{G OPEN ACCESS}

Keywords: resilience, emotion regulation, mother, multiple roles

\section{Introduction}

Family is the smallest unit in society and generally consists of parents and children. A family generally consists of both parents who are married and try to build a harmonious household. The fact is that in society not all families have both parents as a whole. This then gave rise to the concept of single fathers and mothers. Based on data from the Ministry of Women's Empowerment and Child Protection of the Republic of Indonesia, as many as 7 million women in Indonesia became the head of the family due to factors, such as divorce, husbands who migrated, and died [1].

A single mother not only has the responsibility to care for and raise children, but also has to increase household and financial needs because mothers take over the husband's position by becoming a working mother [2]. Tumbage et al.[3] revealed that a series of responsibilities that must be carried out at the same time by a person is called a dual role 
The first problems that are generally encountered come from a financial perspective because a single mother must be the backbone of the family, lack of support from a social and emotional perspective, as well as a psychological aspect due to experiencing the bitter process of losing a partner [4]. The dual role of mothers as single parents is very heavy because this is evidenced by research conducted by Utami \& Hanani [5] which showed how a mother is fully responsible for her child and has to earn a living to meet the daily needs of a family that was originally supported by husband's presence.

Gonzales in [4] revealed that single mothers who become career women also find various conflicts. The work undertaken is basically helpful in terms of finance, but it creates pressure and demands [4]. Another problem is the work schedule is not fixed and they have to migrate to other areas. Problems at work and family have the possibility to conflict with each other [6]. This can actually become a new stressor[2]).

Based on research conducted by Sari \& Yuwono [7], the dual role played by single mothers has the potential to trigger stress due to factors encountered, such as difficulties in dividing and managing time between being busy as a career woman and caring for children, especially at the same time. workload to the demands of meeting the needs of daily life. The definition of stress in the psychological dictionary is a situation that makes a person depressed, both psychologically and physically [8]. The health and quality of life of a mother who experiences stress due to having a dual role between household and work affairs can have a negative impact [9].

One way to deal with stress is to have good emotional regulation because it is related to one's psychological well-being [2]. Emotion regulation is a process of how individuals manage emotional changes in themselves or others [10]. This can be reinforced by previous research conducted by Hasanah \& Widuri [11]regarding the regulation of emotions in single mothers, showing the results that the husband's departure makes single mothers brought up negative emotions in the form of deep sadness.

Based on research conducted by Marliani et al. [2], emotional regulation is an important thing for career mothers to be able to regulate and manage the negative stimuli they experience. If emotion regulation can be applied properly, then a single mother can play a dual role in taking care of children and working optimally. According to Sukmaningpraja \& Santhoso [12], the emotional regulation process can run optimally if single mothers have a skill called resilience.

Resilience is a condition in which a person has the toughness to get up and bounce back after experiencing psychological stress and adversity. The ability of resilience is very important for family life, including a single mother who has to care for and support her child. Resilient families will have hope in the future, even though they are 
experiencing adversity [13]. This also applies to single mothers because in the process of undergoing a dual role, having an optimistic nature will help him in dealing with the obstacles he faces.

Troy \& Mauss [14] suggested that those with optimal emotion regulation tend to have resilience to adversity compared to someone with low emotional regulation ability. If a mother can regulate emotions well, then when faced with stressful situations while undergoing multiple roles, she will be able to grow resilience in herself. Therefore, the subjects in this study were single mothers with multiple roles who entered middle adulthood because they had gone through the period of marriage to divorce. [15].

\section{Literature Review}

Gross [16] revealed that emotion regulation is an individual's ability to manage thoughts, physiology and behavior and can suppress, strengthen or maintain emotions according to their goals. The process of emotion regulation occurs both automatically and controlled as well as consciously and unconsciously can change over time. Human life is inseparable from emotion regulation because cognitive processes and awareness support individuals in managing emotions and feelings to remain stable and not excessive in order to avoid stress in the future. Reivich \& Shatte in Hendriani [17] revealed that emotion regulation is the ability of a person to remain calm even though he is in a stressful condition. Stable emotional regulation abilities can help a person respond when dealing with other people or the environment.

Experts have revealed that resilience is a fundamental ability that a person has in the 21st century [17]. Block (in Klohnen [18]) described the term resilience for the first time with ego-resilience as an effective self-adaptation ability in individuals when faced with internal and external pressures. Luthar [19] explained that resilience is a dynamic process consisting of positive adjustment in difficult conditions and obstacles that can change over time and the environment. Resilience is a picture that shows how a person is able to overcome an obstacle and mobilize all the strength within himself by having a mindset that can be improved by learning to explore ways of thinking in order to develop skills in overcoming problems and finding causes and impacts on life. (Reivich \& Shatte, in Hendriani [17]) 


\section{Method}

This study used a quantitative approach with descriptive correlational analysis which aims to know the description of the research subject and the relationship between variables. The population of this study were single mothers with multiple roles in Malang City. The sampling method that will be used is incidental sampling with 80 participants. In this study it was carried out using a tool in retrieving data, namely the scale. The emotional regulation scale is based on the theory according to Gratz \& Roemer [20] which consisted of four aspects, namely strategies to emotion regulation, engaging in goal directed behavior, control emotional responses, and acceptance of emotional responses. The emotion regulation scale consisted of 18 favorable and 18 unfavorable items. Reliability was calculated using Cronbach's Alpha and obtained a coefficient of 0.941. The resilience scale is compiled using aspects according to Grotberg [21] which consisted of three aspects, namely I Have, I am, and I can. The resilience scale consisted of 34 favorable items and 32 unfavorable items. Reliability was calculated using Cronbach's Alpha and obtained a coefficient of 0.968 .

\section{Result and Discussion}

\subsection{Result}

\subsubsection{Descriptive analysis of emotion regulation}

Based on the categorization table of emotion regulation above, it was found that out of 80 respondents' single mothers who had multiple roles in Malang City had a low level of emotional regulation, 11 (13.75\%) subjects, 56 (70\%) subjects had an intermediate level of emotional regulation, then a total of 13 (16.25\%) subjects had a high level of emotion regulation. These results reveal that in general single mothers with multiple roles in Malang City have a moderate level of emotional regulation.

\subsubsection{Resilience descriptive analysis}

Based on the resilience categorization table above, it was found that of the 80 respondents' single mothers who had multiple roles in Malang City had a low level of resilience as many as 15 (18.75\%) subjects, a number of 50 (62.5\%) subjects were in the medium category, then 50 (62.5\%) subjects were in the moderate category. 15 (18.75\%) subjects 
had a high level of resilience. These results reveal that in general single mothers who have multiple roles in Malang City have moderate resilience.

\subsubsection{Hypothesis test results}

Based on the hypothesis test that has been done using SPSS for Windows Pearson Correlation, the correlation coefficient was 0.697 with $p=0.000<0.05$ which indicates that there is a correlation between emotional regulation variables and resilience in single mothers with multiple roles in Malang City with a degree of strong relationship or correlation. It also shows that there is a positive relationship between emotional regulation variables and resilience, which means that the better the level of emotional regulation of single mothers, the better the level of resilience and vice versa. The better a person's level of resilience, the better the level of emotional regulation.

\subsection{Discussion}

On the emotion regulation variable, categorization was carried out which was divided into three parts, namely high, medium, and low categories. Based on the results of descriptive analysis tests that have been carried out in this study, the results obtained that the emotional regulation scores of single mothers with multiple roles in Malang City is included in the moderate majority category. This condition shows that single mothers with moderate emotional regulation scores have sufficient ability to suppress and maintain emotions according to their goals. Reivich \& Shatte stated that the regulation of emotions possessed by individuals can also be interpreted as an ability to remain calm even in stressful conditions, so as to be able to manage responses when relating and interacting with people in their environment in various situations[17].

The resilience variable has a categorization which is divided into three parts, namely high, medium, and low categories. Based on the results of the descriptive analysis test that has been done previously, the results obtained showed that the majority of single mothers are included in the category of moderate resilience scores. The medium category shows that single mothers have sufficient ability to overcome obstacles by mobilizing all their abilities to develop skills, overcome problems, and find causes [17]. Resilience is also a dynamic process in which there is a role for individual and social or environmental factors to emerge from negative emotional experiences when faced with stressful situations [17]. 
Based on the results of previous research, it was found that there was a significant correlation, meaning that regulation and resilience variables have a strong relationship and influenced each other. The ability of emotional regulation possessed by single mothers with multiple roles affects the level of resilience in the subject, and vice versa.

The results described in the previous paragraph are in line with previous research by Sukmaningpraja \& Santhoso [12], revealing that emotion regulation plays a significant role in a person's resilience process. This shows that the ability to regulate emotions in individuals can affect the level of resilience. Another study was also conducted by Ridwan [22], showed that there was a significant strong correlation between emotion regulation variables and resilience. This statement is reinforced by the research conducted previously by Poegoeh \& Hamidah [23] with the results that a person's emotion regulation strategy increases the level of resilience because it can help individuals face problems in life. Therefore, it can be concluded that the skills of a mother in regulating emotions can support the process of resilience. The emotional regulation of a single mother will help her in managing negative emotions when faced with problems in the midst of her busy life undergoing multiple roles.

Furthermore, there was a positive relationship between emotion regulation and resilience. This means that the better the individual's regulatory ability, the better the level of resilience. Vice versa, the worse the level of emotional regulation, the lower the resilience ability. This is in line with research conducted by Sukmaningpraja \& Santhoso [12], which results in a positive relationship between emotional regulation variable and resilience. The higher the emotional regulation in a person, the higher the resilience.

Subsequent research conducted by Widuri [24] showed that there is a positive correlation between the variables of emotion regulation and resilience, in which the better one's emotional regulation process, the better the resilience process will be. This is also reinforced by research conducted by Karyanta \& Satwika et al. [25] there was a positive relationship between emotion regulation variables and resilience. This relationship shows that the higher one's emotional regulation ability, the higher the resilience.

Dias \& Cadime [26] revealed that good self-regulation has a close relationship with one's resilience, so that if an individual has effective emotional regulation, he will be able to maintain good relations with those around him and adjust to the problems he faces. Reivich \& Shatte (in Hendriani,[17]) revealed that emotion regulation is one of the factors that can affect the success of a person's resilience. The better a person's ability to regulate his emotions, the better the ability of resilience to overcome difficulties when undergoing multiple roles 


\section{References}

[1] Firdaus A. Berdayakan ekonomi keluarga. Kemenpppa. 2016 Feb 19. Available from: https://www.kemenpppa.go.id/index.php/page/read/30/62/berdayakanekonomi-keluarga

[2] Marliani R, Nasrudin E, Rahmawati R, Ramdani Z. Regulasi emosi stres dan kesejahteraan psikologis: Studi pada ibu work from home dalam menghadapi pandemi COVID-19. 2020 May. Available from: https://www.researchgate.net/publication/ 341150701_Regulasi_Emosi_Stres_dan_Kesejahteraan_Psikologis_Studi_Pada_lbu_Work_From_Home

[3] Tumbage SM, Tasik FC, Tumengkol SM. Peran ganda ibu rumah tangga dalam meningkatkan kesejahteraan keluarga di desa allude kecamatan kolongan kabupaten talaud. Acta Diurna Komunikasi. 2017;6(2):1-14.

[4] Faradina AF, F. Konflik pekerjaan-keluarga dan coping pada single mother. Jurnal Psikologi Industri dan Organisasi. 2012;1(2):104-11.

[5] Utami NP, Hanani S. Kebertahanan perempuan simalanggang menjadi single mother. Turast: Jurnal Penelitian dan Pengabdian. 2018;6(1):25-36. https://doi.org/10.15548/turast.v6i1.683

[6] Minnote KL. Family structure, gender, and the work-family interface: Work-to-family conflict among single and partnered parents. Journal of Family and Economic Issues. 2011;33:95-107.

[7] Sari DN, Yuwono S, Psi S. Stres kerja pada ibu single parent [Doctoral dissertation].Surakarta: Universitas Muhammadiyah Surakarta; 2019.

[8] Chaplin JP. Kamus lengkap psikologi terjemahan dr. kartini kartono. Jakarta: Raja Grafindo Persada; 1999.

[9] Candrasari A, Probandari AN. Perbedaan fungsi keluarga dan kualitas hidup istri antara istri bekerja dan tidak bekerja. Biomedika. 2013;5(1):1-7.

[10] Chen $\mathrm{H}$. A theoretic review of emotion regulation. Journal of Social Sciences. 2016;(4):147-153.

[11] Hasanah TDU, Widuri EL. Regulasi emosi pada ibu single parent. Jurnal Psikologi Integratif. 2014;2(1):86-92. https://doi.org/10.14421/jpsi.2014.\%25x

[12] Sukmaningpraja A, Santhoso FH. Peran regulasi emosi terhadap resiliensi pada siswa sekolah berasrama berbasis semi militer. Jurnal Psikologi. 2016;6(3):164-191. https://doi.org/10.22146/gamajop.36944

[13] Walsh F. Strengthening family resilience. New York: Guilford publications; 2006.

[14] Troy AS, Mauss IB. Resilience and mental health: Challenges across the lifespan. Southwick SM, Litz BT, Charney D, et al, editors. Cambridge: Cambridge University 
Press; 2011. Resilience in the face of stress: Emotion regulation as a protective factor; p. 30-44.

[15] Santrock JW. Life-span development (Perkembangan Masa Hidup). Jakarta: Erlangga; 2012.

[16] Gross JJ. Handbook of emotion regulation. New York: The Guilford Press; 2007.

[17] Hendriani W. Resiliensi psikologis; Sebuah pengantar. Jakarta Timur: Prenadamedia Grup; 2018.

[18] Klohnen EC. Conceptual analysis and measurement of the construct ego resilience. Journal of personality and social psychology. 1996;70(5):1067-1079.

[19] Luthar SS. Resilience and vulnerability: Adaptation in the context of childhood adversities. Cambridge: Cambridge University Press; 2003.

[20] Gratz KL, Roemer L. Multidimensional assessment of emotion regulation and dysregulation: Development, factor structure, and initial validation and difficulties in emotion regulation scale. Journal of Psychopathology and Behavioral Assessment. 2004;26(1):41-45.

[21] Grotberg E. Countering depression with the five building blocks of resilience. Reaching Today's Youth. 1999;4(1):66-72.

[22] Ridwan GAS. Pengaruh tingkat regulasi emosi dan tingkat resiliensi pada taruna tahun pertama. NUSANTARA: Jurnal IImu Pengetahuan Sosial. 2020;7(3):565-572. http://dx.doi.org/10.31604/jips.v7i3.2020.565-572

[23] Poegoeh DP, Hamidah H. Peran dukungan sosial dan regulasi emosi terhadap resiliensi keluarga penderita skizofrenia. INSAN Jurnal Psikologi dan Kesehatan Mental. 2016;1(1):12-21. http://dx.doi.org/10.20473/jpkm.V1112016.12-21

[24] Widuri EL. Regulasi emosi dan resiliensi pada mahasiswa tahun pertama. Jurnal Humanitas. 2012;2(9):147-156 . http://dx.doi.org/10.26555/humanitas.v9i2.341

[25] Karyanta NA, Satwika PA. Hubungan antara regulasi emosi dan religiusitas dengan resiliensi pada ibu yang memiliki anak tunagrahita di SLB C YPSLB kerten surakarta. Wacana. 2016;8(2):1-14.

[26] Dias PC, Cadime I. Protective factors and resilience in adolescents: The mediating role of self-regulation. Psicología Educativa. 2017;23(1):37-43. 